\title{
Pilot-Scale Composting Test of Polylactic Acid for Social Implementation
}

\author{
Nobuyuki Kawashima *, Tadashi Yagi (D) and Kouya Kojima \\ Mitsui Chemicals, Inc., 1-5-2 Higashi-Shimbashi, Minato-ku, Tokyo 105-7122, Japan; \\ tadashi.yagi@mitsuichemicals.com (T.Y.); kouya.kojima@mitsuichemicals.com (K.K.) \\ * Correspondence: nobuyuki.kawashima@mitsuichemicals.com; Tel.: +81-3-6253-2923; Fax: +81-3-6253-4247
}

Citation: Kawashima, N.; Yagi, T.; Kojima, K. Pilot-Scale Composting Test of Polylactic Acid for Social Implementation. Sustainability 2021, 13, 1654. https://doi.org/10.3390/ su13041654

Academic Editors: Vincenzo Torretta and Chunjiang An

Received: 14 December 2020

Accepted: 1 February 2021

Published: 4 February 2021

Publisher's Note: MDPI stays neutral with regard to jurisdictional claims in published maps and institutional affiliations.

Copyright: (c) 2021 by the authors. Licensee MDPI, Basel, Switzerland. This article is an open access article distributed under the terms and conditions of the Creative Commons Attribution (CC BY) license (https:// creativecommons.org/licenses/by/ $4.0 /)$.

\begin{abstract}
The chemical industry and subsequent value chain of plastics are facing significant challenges from the viewpoints of resource conversion and environmental burden. Now is the time to explore the future direction of plastics, which will require an integrated scheme using resource circulation, carbon neutrality, and a social system to promote after-use treatment under the concept of a circular economy. Polylactic acid (PLA) should help reduce greenhouse gas (GHG) emissions as a biobased material and contribute to waste management after use due to its biodegradability if managed properly. That is, it will be necessary to treat biodegradable products appropriately in closed systems such as composting facilities after use and recovery. To realize the implementation of fully approved composting facilities in society, simply evaluating biodegradability in the laboratory is insufficient. In this study, a pilot-scale test using PLA under actual composting conditions was conducted in accordance with both international standards and domestic evaluation methods. The results not only confirm its biodegradability and disintegration, but also demonstrate that the presence of a biodegradable plastic product has a negligible impact on the composting process. The obtained compost did not adversely affect plant germination or growth, demonstrating its safety and high quality. Such a multifaceted perspective makes this study unique and useful for creating a social framework.
\end{abstract}

Keywords: PLA; biodegradability; composability; pilot-scale compost; circular economy; social implementation

\section{Introduction}

In the early 1990s, biodegradable plastics [1,2] attracted attention as a potential solution for waste treatment problems associated with the shortage of landfills and environmental concerns, which were represented by fur seals entangled in fishing nets. Although extensive development was conducted, market growth was slower than biodegradable plastics manufacturers expected because sorting biodegradable products from non-biodegradable products was not trivial, and the necessary infrastructure to treat biodegradable products appropriately was not well developed.

The Kyoto protocol reinvigorated interest in biobased plastics such as polylactic acid (PLA) [3] since they should contribute to a reduction in greenhouse gas (GHG) emissions as they are renewable plant resources as opposed to fossil fuel resources. Around 2005, market growth was slowing due to various reasons: difficulty collecting and sorting products, insufficient properties compared with alternative products such as polyethylene terephthalate (PET), use of edible resources, and decreased cost competitiveness with fossil fuel resources caused by a decline in oil prices. It was ironic that regulations and social systems developed for environmental protection hindered advances in innovative environmentally sound products [4].

In 2015, the Sustainable Development Goals (SDGs) were adopted. To achieve these goals, the chemical industry is expected to transfer raw material sources from fossil fuel 
resources to renewable resources as well as reduce GHG emissions via an integrated lifecycle from raw materials to waste treatment after use. Furthermore, from the perspective of a circular economy [5], it is necessary to build a social system that promotes not only resource circulation, including recycling of plastic products, but also carbon neutrality and effective waste treatment after use. After an extended hiatus, PLA is once again gaining momentum because it should contribute significantly to GHG emission reduction and environmentally sound waste treatment together with organic waste $[4,6,7]$. However, PLA alone cannot solve such environmental problems. In addition to the viewpoints of carbon footprint and LCA from raw materials to disposal, it is necessary to evaluate PLA from the viewpoints of edibility (whether it is edible or not) and SDGs, including human rights and land use.

Currently, the estimated global PLA production capacity is about 300,000 tons, of which Corbion Total produces 75,000 tons, NatureWorks produces 150,000 tons, and China manufactures several tens of thousands of tons. Although current PLA manufacturing technology employs the lactide method [7,8], a direct polycondensation method of lactic acid has been demonstrated at the semi-commercial level $[3,7,9]$. The operating rate and actual sales volume are unknown. However, there is a shortage of goods globally.

The claim of reducing GHG emissions is emphasized from the viewpoint of carbon neutrality as it is derived from biomass rather than biodegradability. It is unknown whether recovery or composting after use is performed to take advantage of its biodegradability. However, cases of closed systems are becoming more common (e.g., Furano City, Lark Burger). Biodegradable plastics, including PLA, can help reduce the environmental load if properly collected and treated after use. However, the word biodegradable may promote littering, which is a moral hazard.

PLA holds promise for containers and packaging, garbage bags, and agricultural materials such as mulch. Its compost is expected to play an important role in disposing of these products. However, for social implementation, that is, acceptance at composting facilities, demonstrating its biodegradability on the laboratory scale is not enough. For commercial-level use of biodegradable plastic products, the quality and safety of the resulting compost, as well as its degradability and disintegration, must be confirmed on the pilot scale to model an actual composting facility and an environmentally sound composting process. In addition, good growth of agricultural products using the obtained compost must be established. Although many papers were published from the early 1990s to 2019 relating to the biodegradability of PLA in compost as well as the quality and safety of the resulting compost, few papers reported a comprehensive and holistic approach on the pilot scale that included an evaluation of plant growth.

The purpose of this study is to demonstrate the importance of a pilot-scale composting test, rather than a laboratory test, to show that composting is the proper treatment method for social implementation after using packaging made of PLA contaminated with food waste. The degradability of the product, impact on the composting process, and quality and safety of the obtained compost were examined. As a result, we confirmed that both biodegradability and disintegration are demonstrated under actual composting conditions on the pilot scale, and the presence or absence of PLA products does not affect the composting process. Furthermore, the obtained compost is high quality and safe and does not show adverse effects on plant growth. This type of comprehensive pilot-scale compost test should be useful to design a social system to treat organic waste together with biodegradable products after use.

\section{Materials and Methods}

\subsection{PLA Sample and Compost Raw Materials}

\subsubsection{Standard Biodegradability Test of PLA in Compost}

According to ISO 14855 [10], in the basic test, which indicates the biodegradability of PLA, PLA powder and mature compost from a compost facility in Hayakita-cho, Hokkaido, 
were used at $58 \pm 2{ }^{\circ} \mathrm{C}$. ISO 14755 [10] was later modified into ISO 14855-1 [11] and ISO 14855-2 [12], although the basic principles remained the same.

\subsubsection{Biodegradability and Disintegration of PLA Products in the Pilot-Scale Compost}

PLA film-laminated paper plates, which are a BPS certified Green Plastic \#216 provided by Tohcello, were used in the pilot-scale compost test. BPS was formerly the Biodegradable Plastics Society, but its name changed to the Japan Bioplastics Association (JBPA). Green Plastic is the brand name of the biodegradable plastics. The plates were composed of a $40 \mu \mathrm{m}$-thick PLA film made from LACEA ${ }^{\mathrm{TM}}$ (Mitsui Chemicals) and a paper part made from $100 \%$ pulp paper with a weight of $320 \mathrm{~g} / \mathrm{m}^{2}$ (Figure 1).

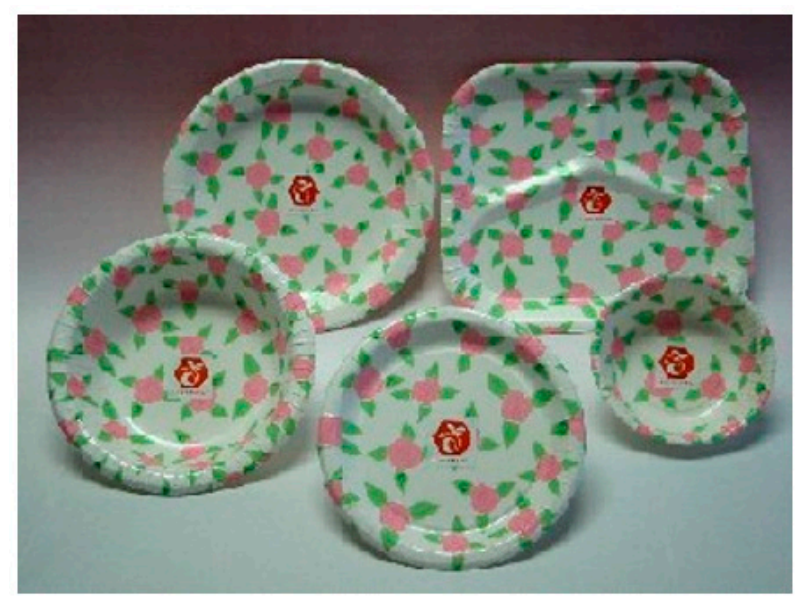<smiles>C[C@@H](O[10CH3])C(=O)O[C@H](C)C(=O)C(C)(C)C</smiles>

Figure 1. PLA film-laminated paper plates as a test sample.

In accordance with ISO 16929 [13], the raw material for compost was wood chips as an auxiliary material, horse and animal waste as return compost, and plant-based waste as a substitute for fermentation with artificial garbage. Table 1 shows the composition ratios of these compost raw materials.

Table 1. Formation of the composting materials.

\begin{tabular}{ccc}
\hline Component & Description & Weight (wet, kg) \\
\hline & Feed for rabbits (solid compounded feed) & 9 \\
& Cabbage & 28 \\
& Potato & 5.4 \\
Plant-based waste & Onion & 5 \\
& Tomato & 4.6 \\
& Banana & 3.2 \\
& Carrot & 1.8 \\
& Cucumber & 1.7 \\
& Grapefruit & 1.5 \\
\hline Supplied compost & Horse dung compost product & 40 \\
Auxiliary raw material & Larch & 10 \\
Total & & 110.2 \\
\hline
\end{tabular}

PLA pellets were provided by Mitsui Chemicals and processed into PLA film by Tohcello. PLA film was laminated with $100 \%$ pulp paper. Then, the PLA film-laminated paper was thermoformed into plates.

\subsection{Test Equipment and Processing Conditions}

\subsubsection{Biodegradability Standard Test of PLA in Compost}

In the standard model of ISO 14855 [10], about $100 \mathrm{~g}$ of a sample is put into about $600 \mathrm{~g}$ of compost. Figure 2 shows a newly developed small-scale model. In this model, 
about $5 \mathrm{~g}$ of a sample was put into $100-500 \mathrm{~g}$ of compost. The temperature was kept at $58 \pm 2{ }^{\circ} \mathrm{C} . \mathrm{CO}_{2}$ generated by biodegradation was absorbed by the alkaline solution and measured by titration.

\section{Flow Controller}

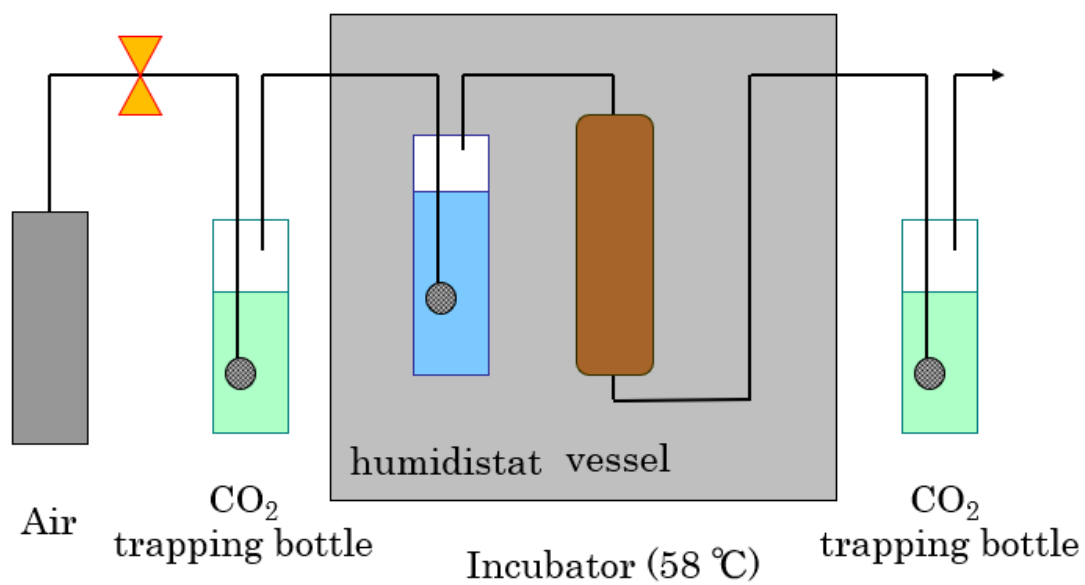

Figure 2. Scheme of the laboratory-scale compost apparatus according to ISO 14855.

2.2.2. Biodegradability and Disintegration of the PLA Product in Pilot-Scale Compost

Each fermenter was a $180 \mathrm{~L}$ metal columnar drum (without a stirring mechanism) equipped with a blower with an airflow meter, non-dispersive infrared absorption (NDIR)type $\mathrm{CO}_{2}$ concentration meter, thermometer, and other measurement equipment (Figure 3). Table 2 summarizes the list of auxiliary apparatus.

Blank zone: w/o PLA sample Test zone: w/ PLA sample

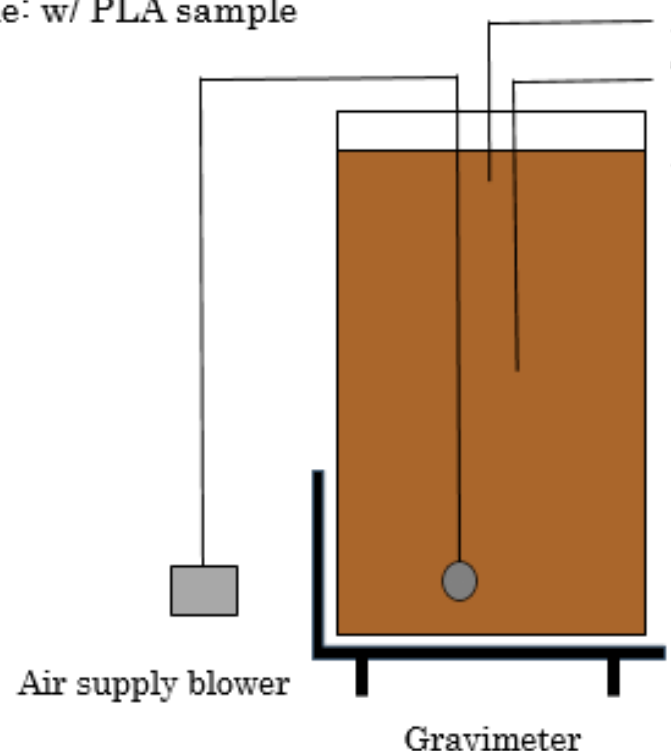

Temp. at the top: measured daily

Temp. at the center, $\mathrm{CO}_{2}, \mathrm{O}_{2}, \mathrm{NH}_{3}$ : measured daily

\section{Other items} measured weekly.

Fermentation

\section{Drum}

Figure 3. Scheme of the pilot-scale compost apparatus principle. 
Table 2. List of auxiliary apparatus used in the pilot-scale compost experiment.

\begin{tabular}{|c|c|c|}
\hline Apparatus & Device & Description \\
\hline Air supply & $\begin{array}{l}\text { Blower } \\
\text { Air flow meter } \\
\text { Air supply pipe }\end{array}$ & $\begin{array}{c}\text { Roots-type blower } \\
\text { Flow-rate control type airflow meter with a needle valve } \\
\text { PVC loop-type air supply pipe }\end{array}$ \\
\hline Gas meters & $\begin{array}{l}\mathrm{CO}_{2} \text { meter } \\
\text { Collection device } \\
\text { Selection switch } \\
\text { Mist separator } \\
\text { Recorder }\end{array}$ & $\begin{array}{c}\text { NDIR gas meter } \\
\text { Diffused gas collector made of PET } \\
\text { Electromagnetic valve } \\
\text { Liquid displacement type } \\
\text { Intermittent recorder (also used for temperature) }\end{array}$ \\
\hline Thermometer & $\begin{array}{l}\text { Temperature sensor } \\
\text { Recorder }\end{array}$ & $\begin{array}{l}\text { JIS Pt100 platinum temperature measurement resistor } \\
\text { Intermittent recorder (also used for gas) }\end{array}$ \\
\hline
\end{tabular}

Fermenters, which contained $170 \mathrm{~L}$ of compost raw materials, were prepared and divided into two zones (Figure 4). In the test zone, PLA samples $(1.1 \mathrm{~kg}$ ) were added to the fermenter (Figure 5). In the blank zone, the fermenter did not contain PLA samples. To confirm the validity, each zone was duplicated. After the test was completed, the contents of the fermenter in each treatment area were sieved to separate particles of non-disintegrated PLA samples with a diameter greater than $2 \mathrm{~mm}$, and as a result the residual rate of PLA samples was measured. The maximum test treatment period was 80 days. However, biodegradation was completed within about 60 days. The test ended after confirming that fermentation had stopped, which was determined when fermentation conditions such as $\mathrm{CO}_{2}$ concentration and temperature no longer changed over time.

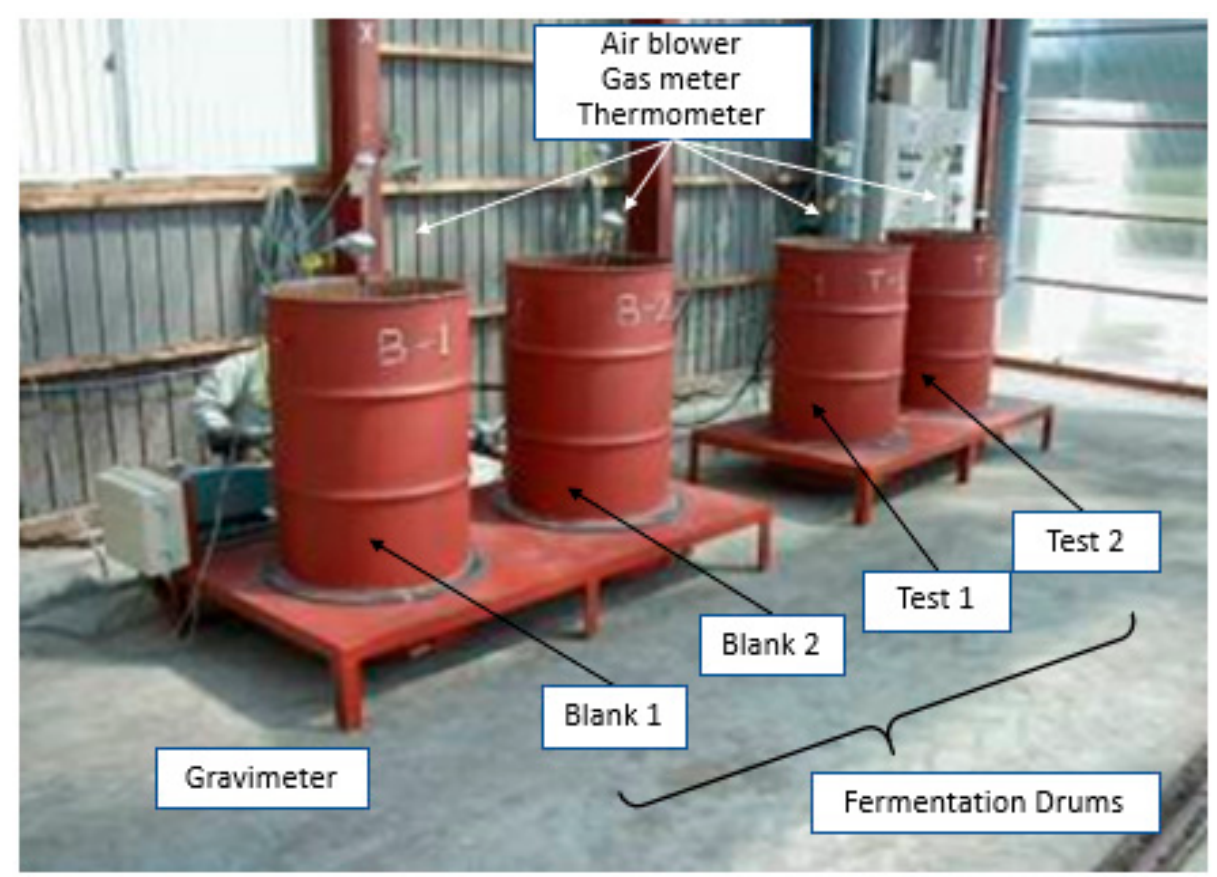

Figure 4. Photo of the pilot-scale compost apparatus. (left) Two drums are the blank zone without PLA samples and (right) two drums are the test zone with PLA samples. All drums were equipped with an air blower, gas concentration meter, and thermometer. Drums were placed on a gravimeter.

The temperature depended on the heat generated by biodegradation of the compost. External heat was not added.

Table 3 summarizes the measured items.

Test sample: PLA film-laminated paper plates were put into the compost after cutting into $5 \times 5 \mathrm{~cm}$ pieces. 
The test zone contained the PLA sample, whereas the blank zone did not. Table 1 shows the compost raw materials. The PLA sample was a PLA film-laminated paper plate cut into $5 \times 5 \mathrm{~cm}^{2}$ pieces. Table 4 shows the conditions.

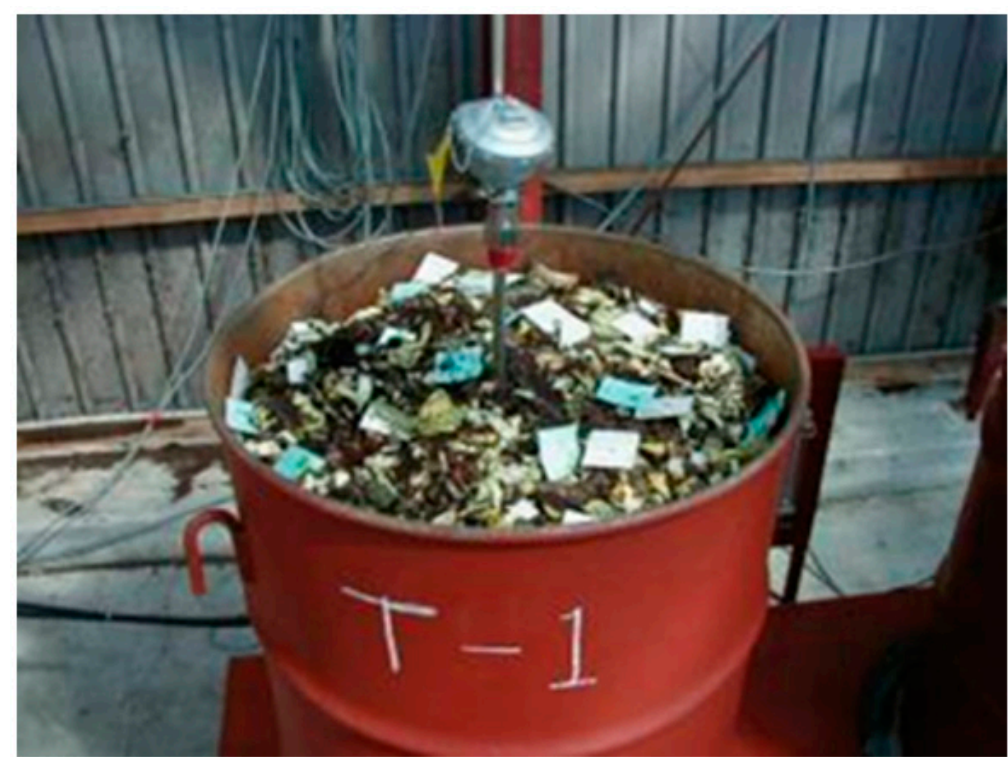

Figure 5. PLA test sample in the pilot-scale compost apparatus.

Table 3. Measured items.

\begin{tabular}{lll}
\hline \multicolumn{1}{c}{ Item } & \multicolumn{1}{c}{ Method } & \multicolumn{1}{c}{ Measurement Frequency and Remarks } \\
Temperature & JIS Pt100 & $\begin{array}{l}\text { Daily, continuous measurement } \\
\text { Top: } 15 \mathrm{~cm} \text { from the surface } \\
\text { Center: } 40 \mathrm{~cm} \text { from the surface }\end{array}$ \\
\hline $\mathrm{CO}_{2}$ concentration & Gas detector, NDIR & $\begin{array}{l}\text { Daily, continuous measurement } \\
40 \mathrm{~cm} \text { from the surface }\end{array}$ \\
\hline $\mathrm{O}_{2}$ concentration & Gas detector & $\begin{array}{l}\text { Daily, frequency varies with the change in the measurement value } \\
40 \mathrm{~cm} \text { from the surface }\end{array}$ \\
\hline $\mathrm{NH}_{3}$ concentration & Gas detector & $\begin{array}{l}\text { Daily, frequency varies with the change in the measurement value } \\
40 \mathrm{~cm} \text { from the surface }\end{array}$ \\
\hline $\begin{array}{l}\text { Water content } \\
\text { Ignition loss }\end{array}$ & Weight method & $\begin{array}{l}\text { Weekly, at the time of turning } \\
\text { pH }\end{array}$ \\
$\begin{array}{l}\text { EC } \\
\mathrm{C} / \mathrm{N}_{2} \text { ratio }\end{array}$ & Weight method \\
$\begin{array}{l}\text { Contents volume } \\
\text { Contents weight } \\
\text { Amount of water added }\end{array}$ & Glass electrode & $\begin{array}{l}\text { Weekly, at the time of turning } \\
\text { Weekly, at the time of turning }\end{array}$ \\
\hline
\end{tabular}

Table 4. Operating conditions (according to ISO 16929 [13]).

\begin{tabular}{cc}
\hline Item & Operation Condition \\
\hline Agitation/turning & Drum contents were spread on the sheet, stirred manually, and returned to the drums each week. \\
Air supply & 5 to $25 \mathrm{~L} / \mathrm{min} / \mathrm{m}^{3}$ (Value was set such that the oxygen concentration in the compost was above $5 \%$ ). \\
Water addition & Water was added such that the water content of the compost would not fall below $50 \%$ when turning the compost. \\
Nitrogen control & Urea solution was added to compensate for the drop in the nitrogen concentration due to the addition of water. \\
\hline
\end{tabular}

\subsection{Measurement Items}

\subsubsection{Biodegradability Standard Test of PLA in Compost}

The $\mathrm{CO}_{2}$ generated by biodegradation was measured according to ISO 14855 [10]. 


\subsubsection{Biodegradability and Disintegration of PLA Product in Pilot-Scale Compost}

The tests measured the following: temperature, $\mathrm{CO}_{2}, \mathrm{O}_{2}, \mathrm{NH}_{3}$, water content, loss on ignition, $\mathrm{pH}$, electrical conductivity (EC), carbon/nitrogen ratio, content volume, content weight, and added water weight. At the end of the test, the PLA sample residual rate was measured. For the compost input, the elution test described in the Waste Management and Public Cleaning Act was conducted [14]. For the treated compost, the water, nitrogen, and heavy metal contents were analyzed according to the items described in the Fertilizer Regulation Act in Japan [15].

The blank zone and test zone were each measured twice and graphed with their average values. They appear on the graph as an error bar and a circle of the average value.

Items were measured to confirm whether composting progressed smoothly. For example, the ignition loss and EC indicated whether or not the compost was suitable as fertilizer by evaluating the degree of decomposition of organic matter and salt concentration. On the other hand, the carbon/nitrogen ratio determined the balance between carbon and nitrogen as a fertilizer. Composting proceeded as usual even if PLA was present.

\subsection{Plant Growth}

Finally, the effect of the resulting compost on the germination and growth of Japanese komatsuna (Japanese mustard spinach) was evaluated. The resulting compost was used as a fertilizer. B-1 and B-2 were obtained from compost without the PLA sample. T-1 and T-2 were grown in the compost with the PLA sample based on the test method [16] of plant growth. This method measures toxicity against plants and is regulated by the Ministry of Agriculture, Forestry and Fisheries in Japan No. 1943 (18 April 1984). Komatsuna seeds were buried in each type of fertilizer to observe the effects of the presence of the PLA sample.

\section{Results and Discussion}

\subsection{Biodegradability Standard Test of PLA in Compost}

Tracing the biodegradability of PLA powder using the amount of $\mathrm{CO}_{2}$ generated in the mature compost confirmed that about $88 \%$ of the PLA decomposed in 90 days (Figure 6).

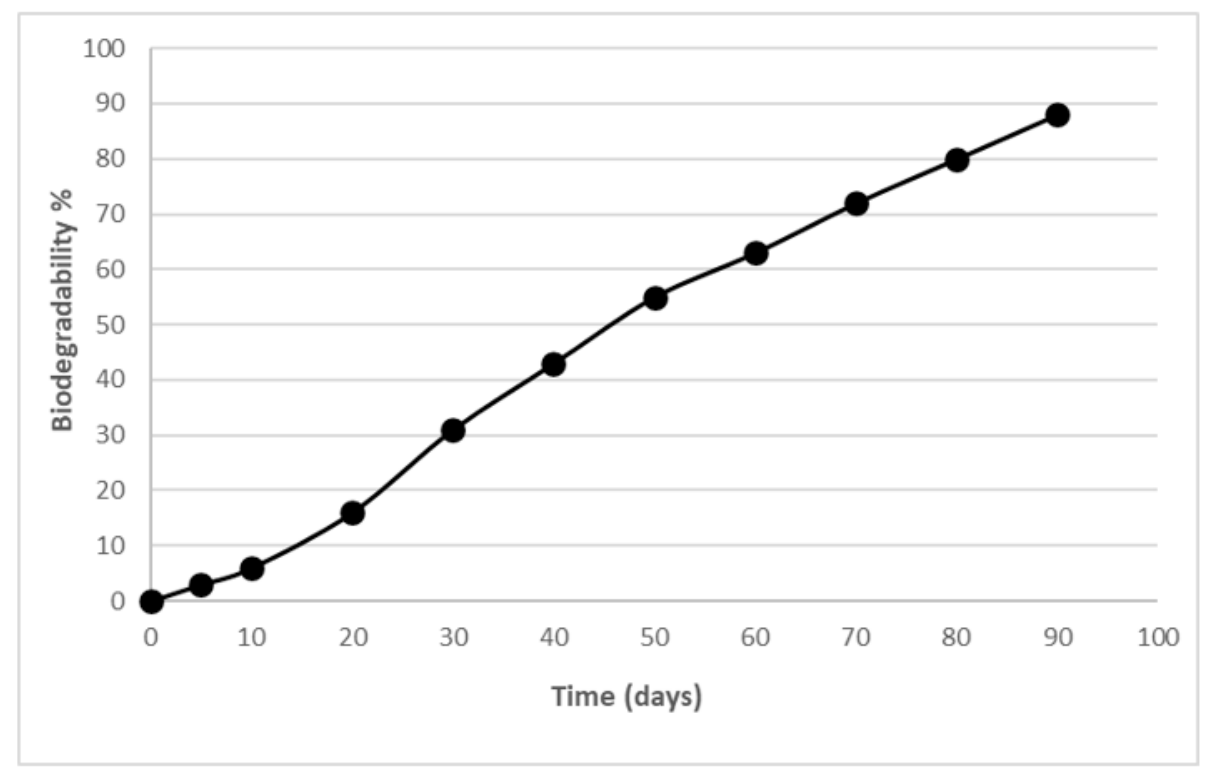

Figure 6. Biodegradability index of the PLA powder measured by the amount of $\mathrm{CO}_{2}$ emission according to ISO 14855. 
3.2. Biodegradability and Disintegration of PLA Products in the Pilot-Scale Compost

3.2.1. Changes in the Temperature and Gas Concentration in the Fermenter

The temperature during the test period was measured at the top (Figure 7) and center of the fermenter (Figure 8). The blank and test zones did not differ significantly as both showed a temperature of $65{ }^{\circ} \mathrm{C}$ or higher for a minimum of $48 \mathrm{~h}$ at the early stage of fermentation. Hence, the compost meets the test standards of ISO 16929 and the epidemiological conditions of Japan.

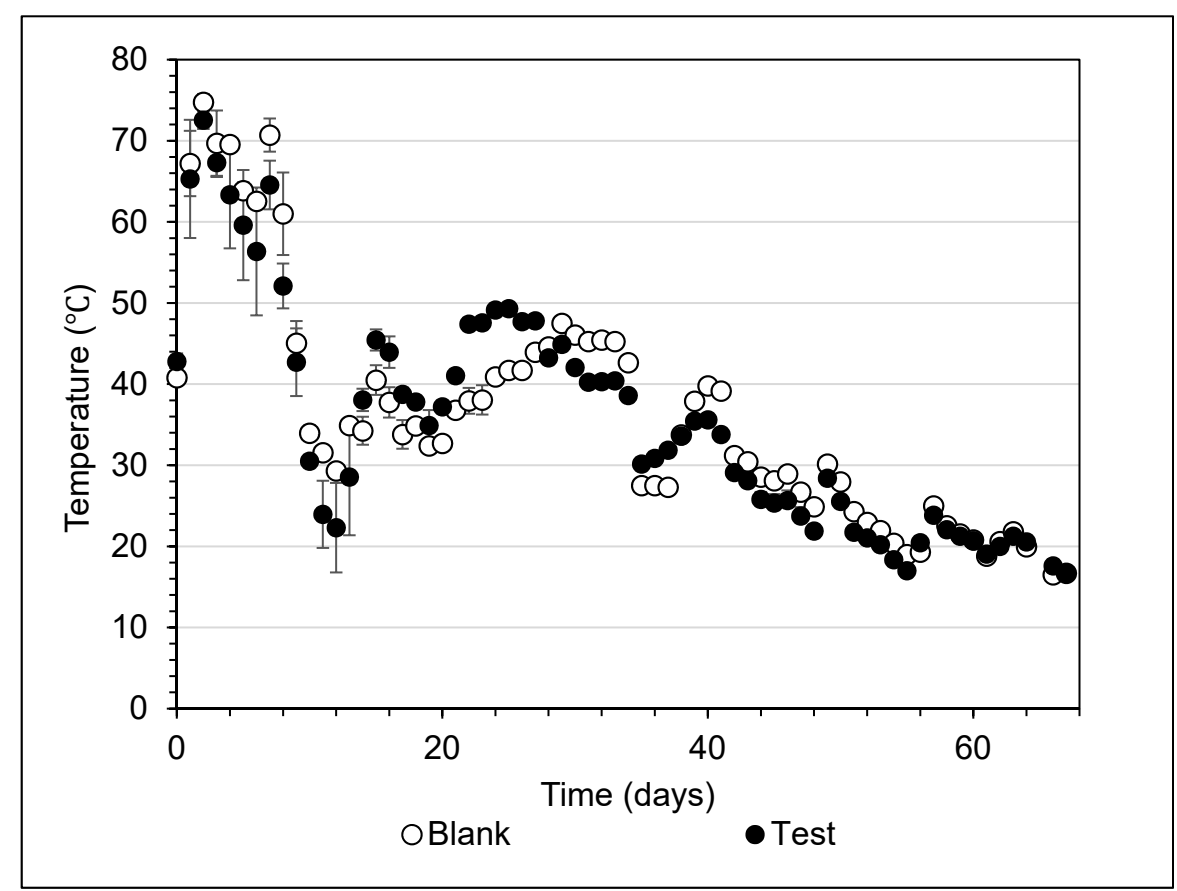

Figure 7. Change in the average temperature at the top $(15 \mathrm{~cm}$ from surface) of the fermentation drum.

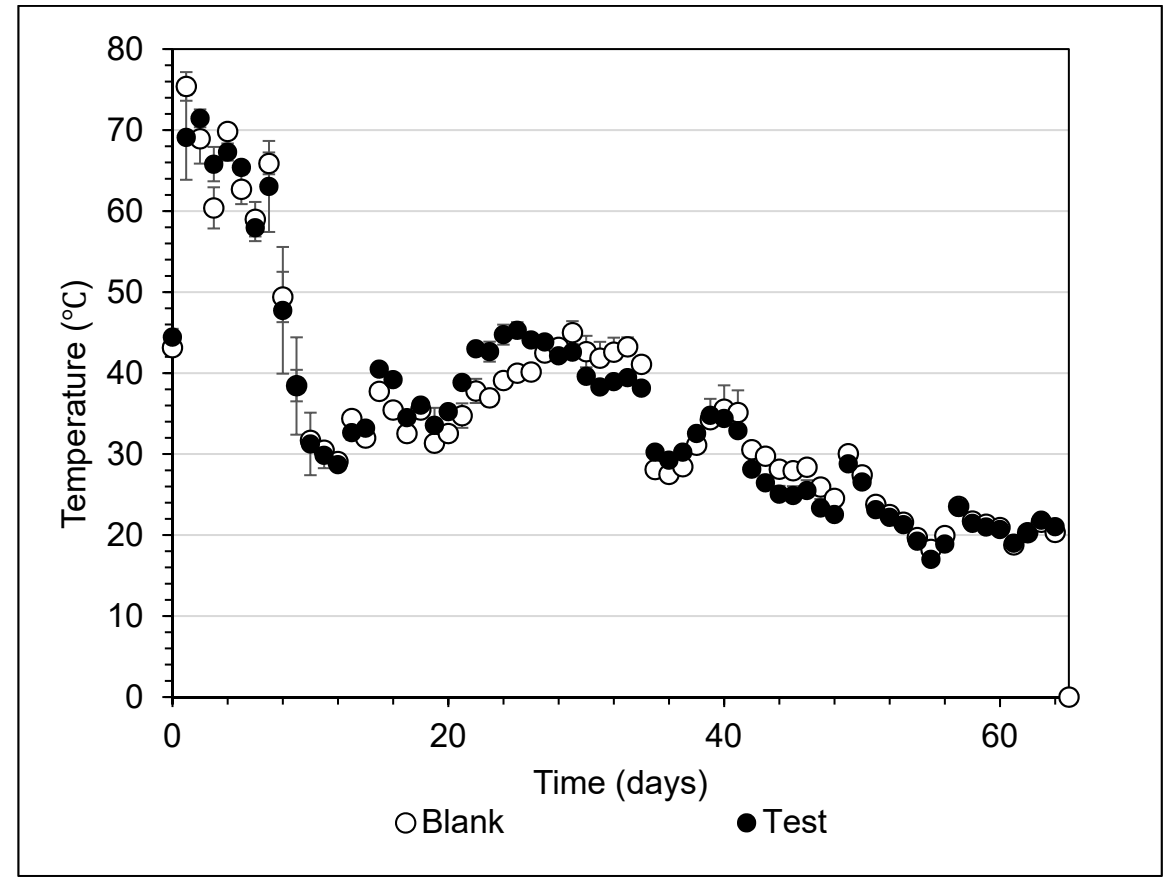

Figure 8. Change in the average temperature at the center $(40 \mathrm{~cm}$ from the surface) of the fermentation drum. 
Figure 9 shows the daily change in $\mathrm{CO}_{2}$ content in both the blank and test conditions. The content initially increased, but then decreased rapidly. From 10-50 days, the content was $0-5 \%$, but it settled at around $1 \%$ or less after 50 days. There are some points that do not overlap in the data of the blank zone and the test zone, but when comparing the behavior before and after, there is no significant difference between the two zones.

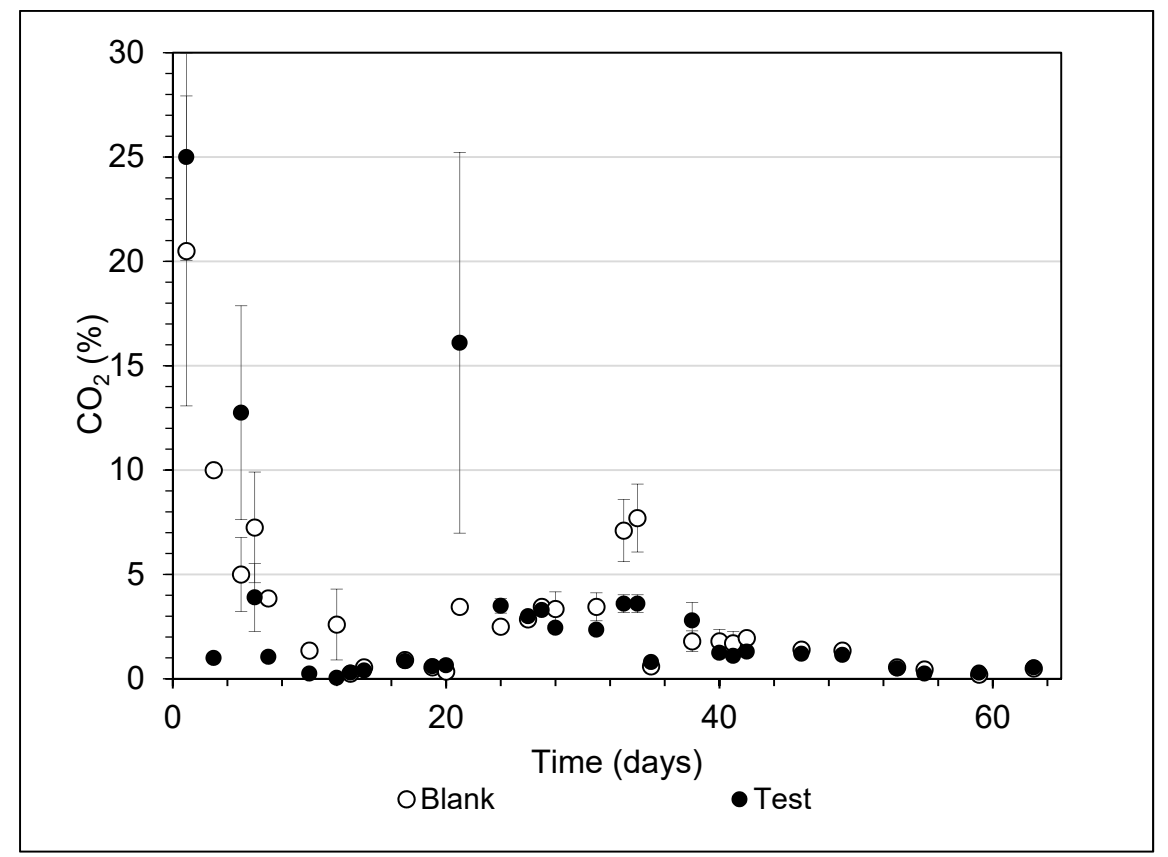

Figure 9. Change in the average $\mathrm{CO}_{2}$ content with time.

Figure 10 plots the daily change in $\mathrm{O}_{2}$ content. As $\mathrm{O}_{2}$ consumption was intense at the beginning of fermentation, it dropped to less than $10 \%$. After 10 days, it stabilized at over $10 \%$ of the $\mathrm{O}_{2}$ content by adjusting the air supply rate. Similar to the trends of $\mathrm{CO}_{2}$ content, although there are some irregular points, the blank and test zones did not differ significantly.

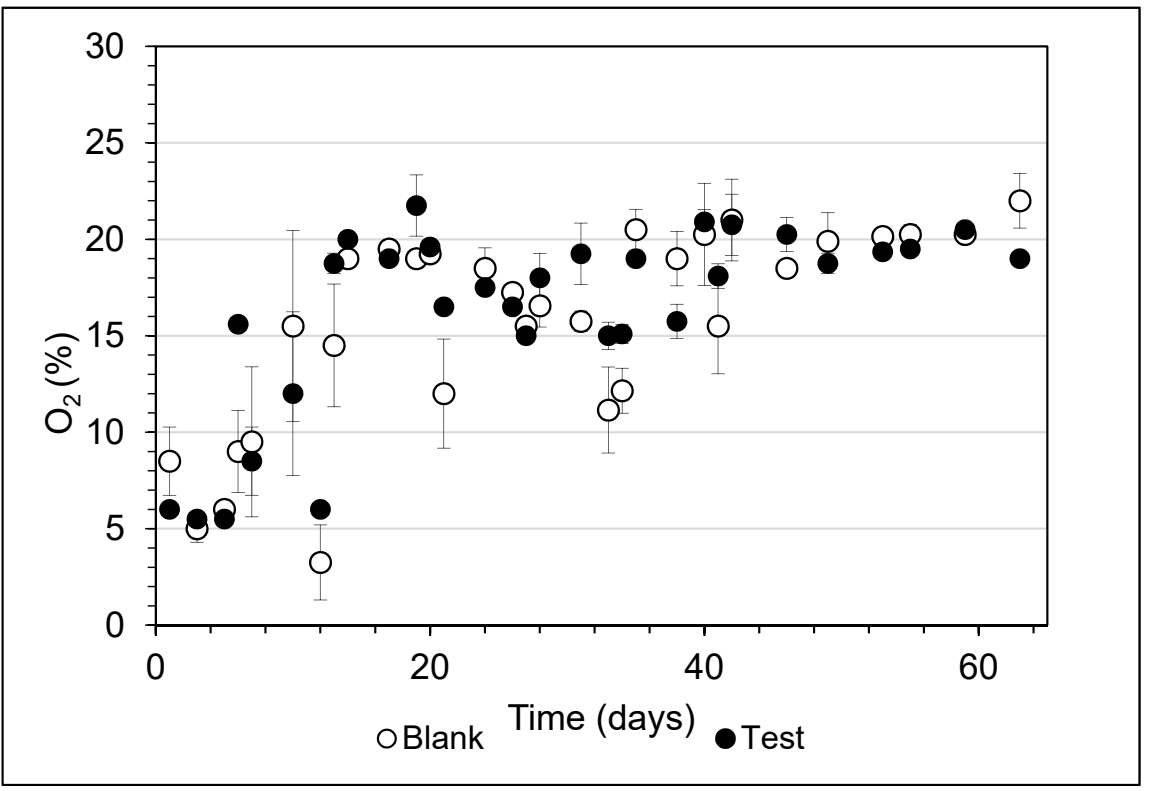

Figure 10. Change in the average $\mathrm{O}_{2}$ content with time. 
The $\mathrm{NH}_{3}$ concentration in the fermenter was initially high but decreased after 20 days (Figure 11). The data from the large error bar at around the 40 day mark may appear irregular, but when comparing it to the decomposition behavior of the two zones at other periods, there were no significant differences.

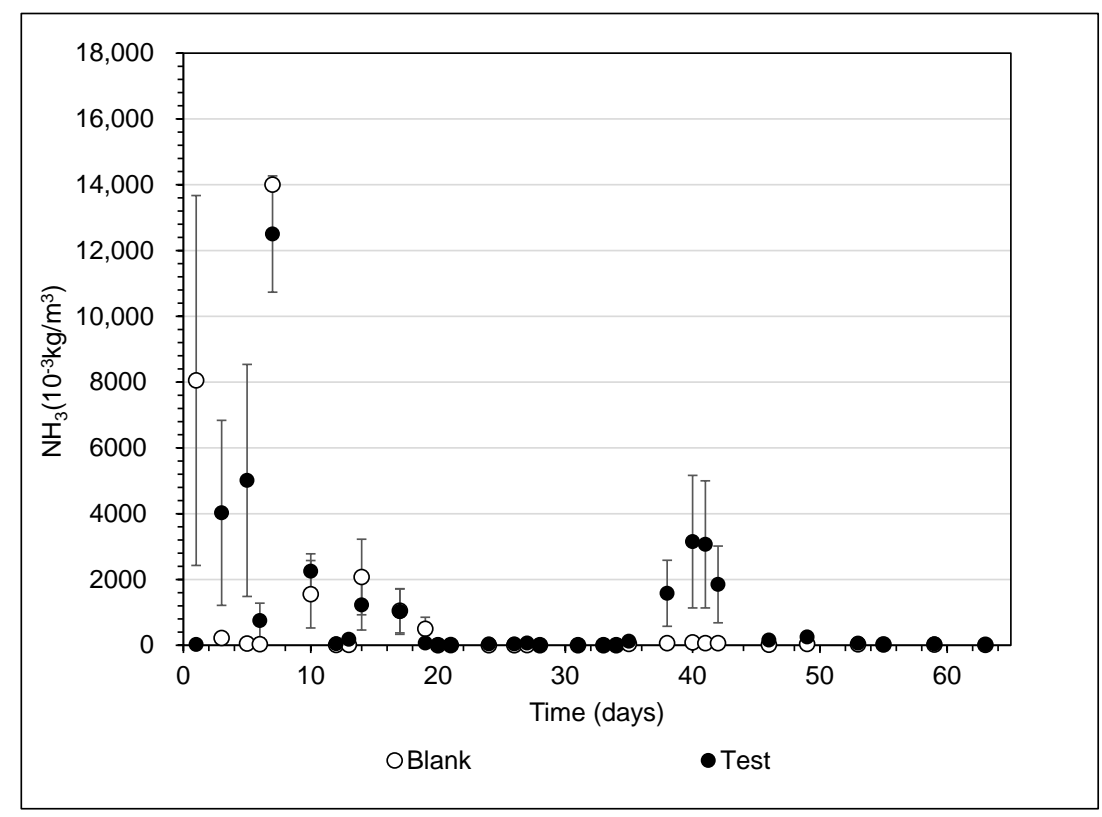

Figure 11. Change in the average ammonia concentration with time.

The similar trends in the temperature, $\mathrm{CO}_{2}, \mathrm{O}_{2}$, and $\mathrm{NH}_{3}$ concentrations in the blank and test zones indicate that the presence of the PLA film did not affect the composting process.

\subsubsection{Property Changes to the Fermentation Mass in the Fermenter}

The test (treated) and blank (untreated) zones did not significantly differ with regard to water content, $\mathrm{pH}, \mathrm{EC}$, and residual amount of ignition during the test period (Figures 12-15).

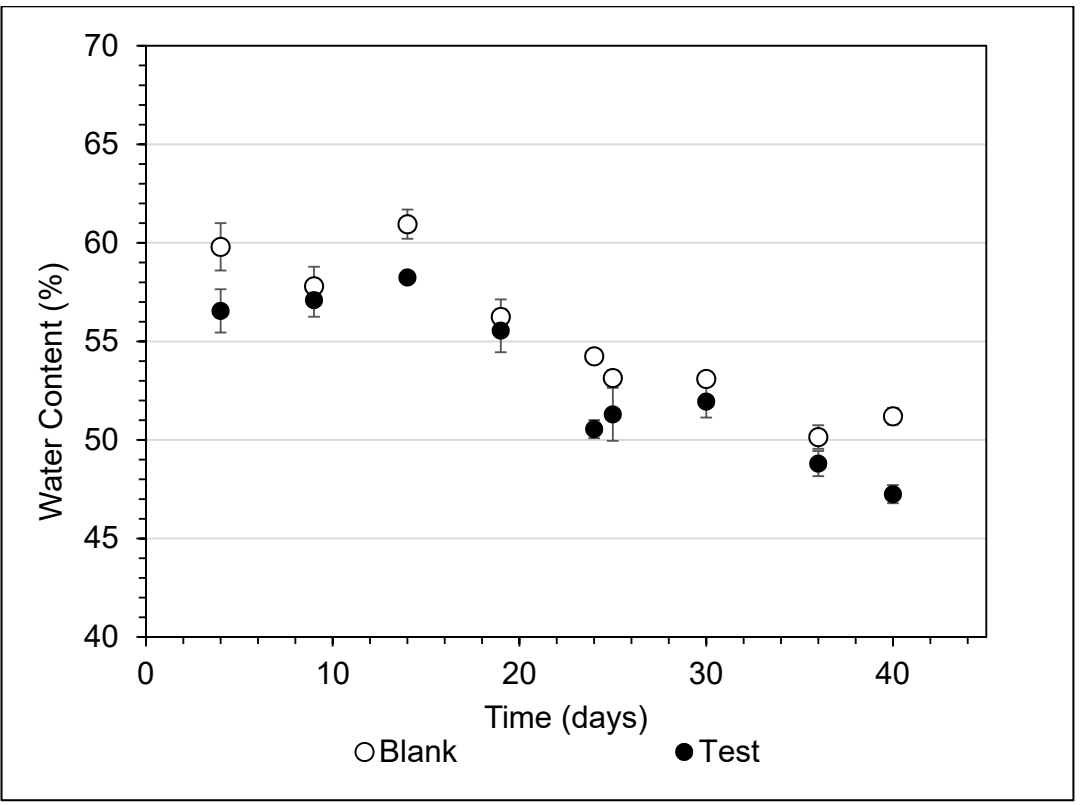

Figure 12. Change in water content with time. 


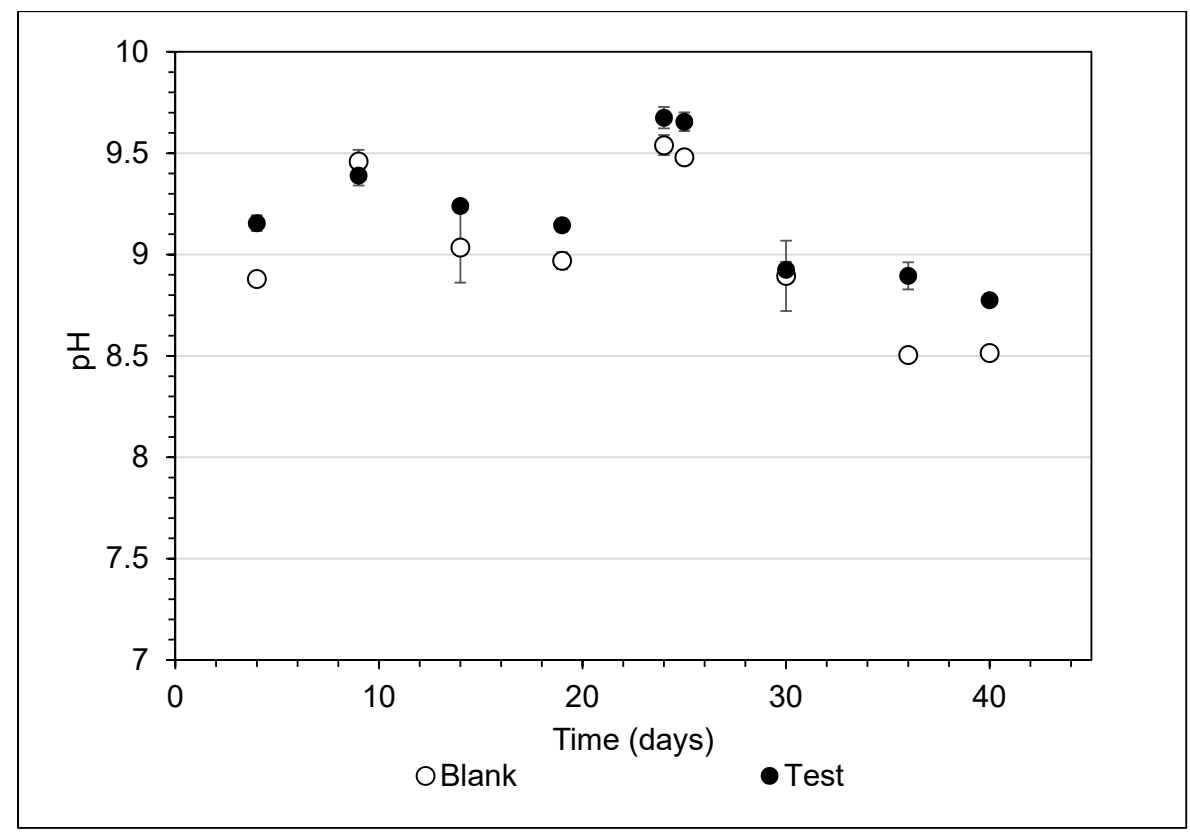

Figure 13. Change in $\mathrm{pH}$ with time.

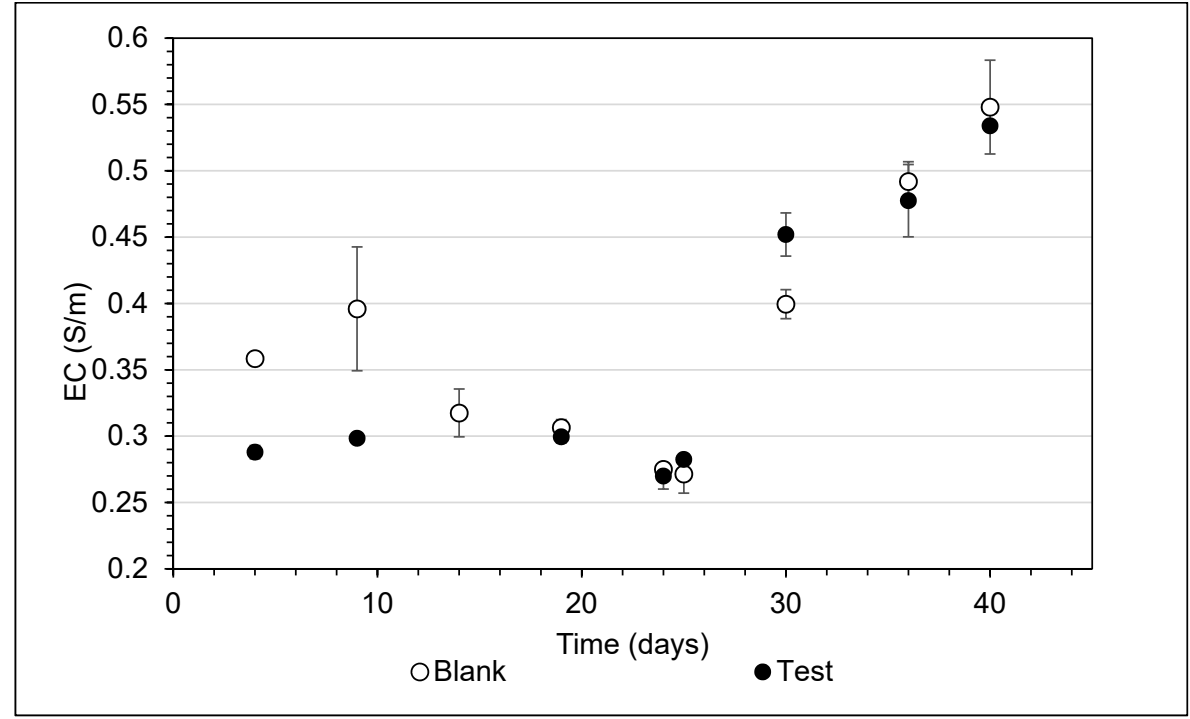

Figure 14. Change in electrical conductivity with time.

Figures 16 and 17 show the weight per container and bulk specific gravity measured during the test period, respectively. The test and blank zones showed similar results. These results further demonstrate that the presence of PLA film-laminated paper did not affect the composting process.

\subsubsection{Residual Rate of the PLA Sample at the End of Test}

To investigate the residual rate of PLA samples, the compost after the test was passed through a $2 \mathrm{~mm}$ sieve. The PLA sample remaining in the compost with a diameter of $2 \mathrm{~mm}$ or more was $0.054 \mathrm{~kg}$, and the residual rate was $5.23 \%$ compared with the input PLA sample by dry weight. Table 5 shows the average weight of each zone at the end of the test. Overall, $94.8 \%$ of the PLA sample, which weighed $1.031 \mathrm{~kg}$ at the time of input, decomposed. Furthermore, fermentation did not vary significantly between the blank and test zones. These results provide additional evidence that the presence of PLA film-laminated paper does not affect the composting process. 


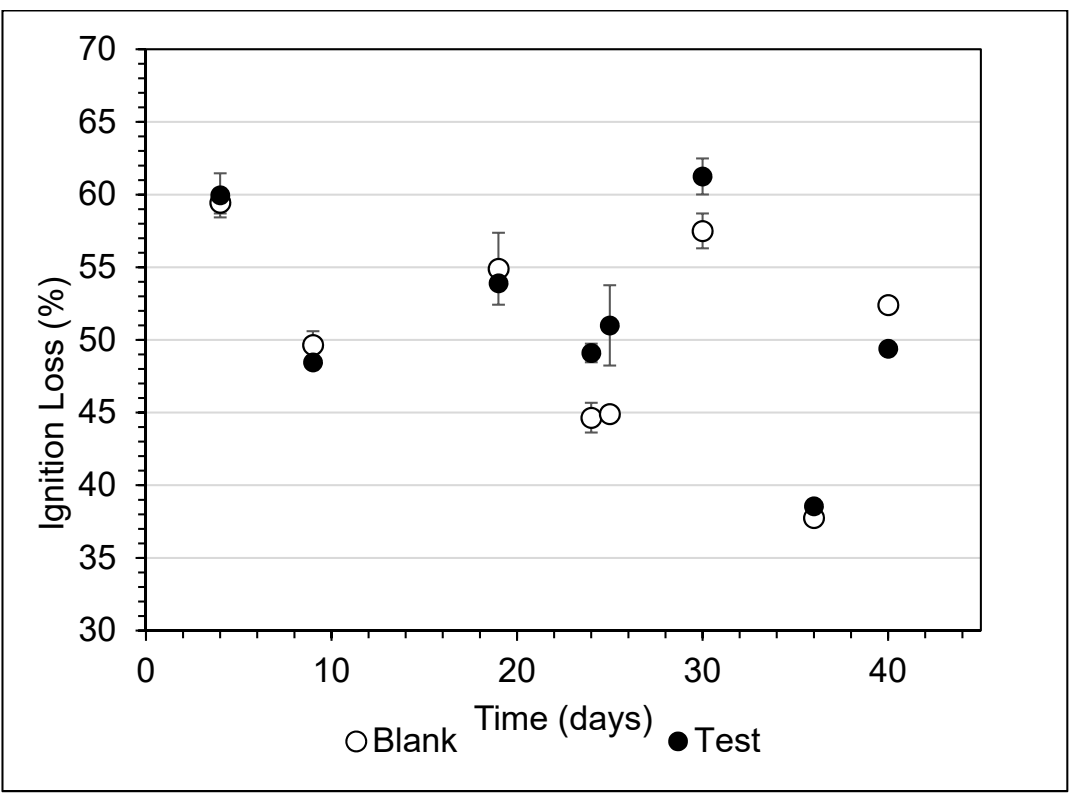

Figure 15. Change in ignition loss with time.

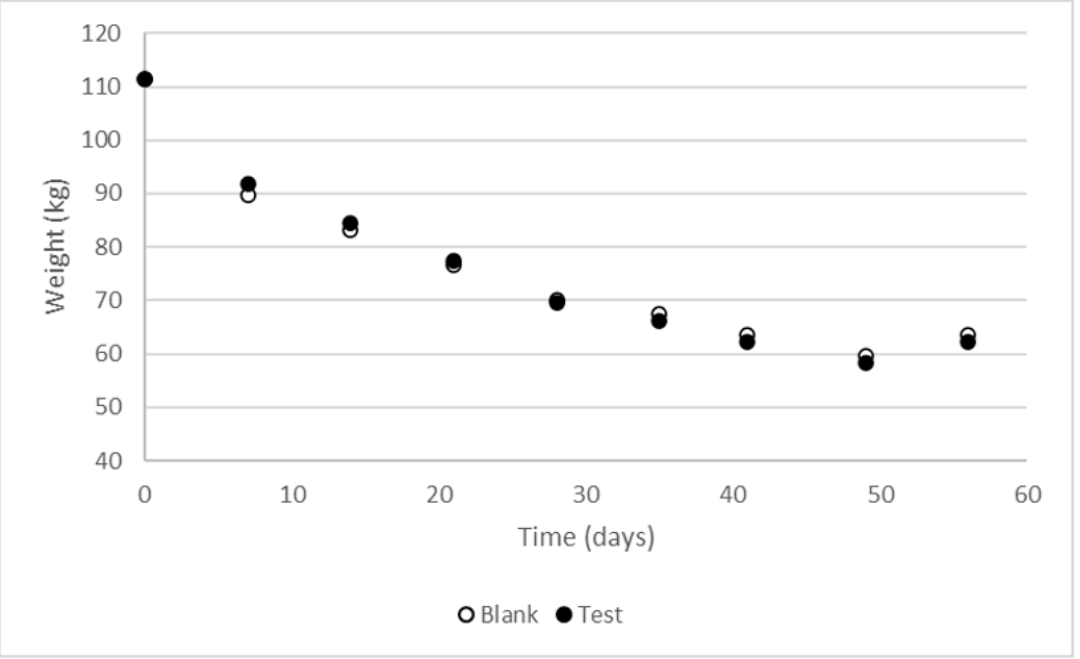

Figure 16. Change in weight with time.

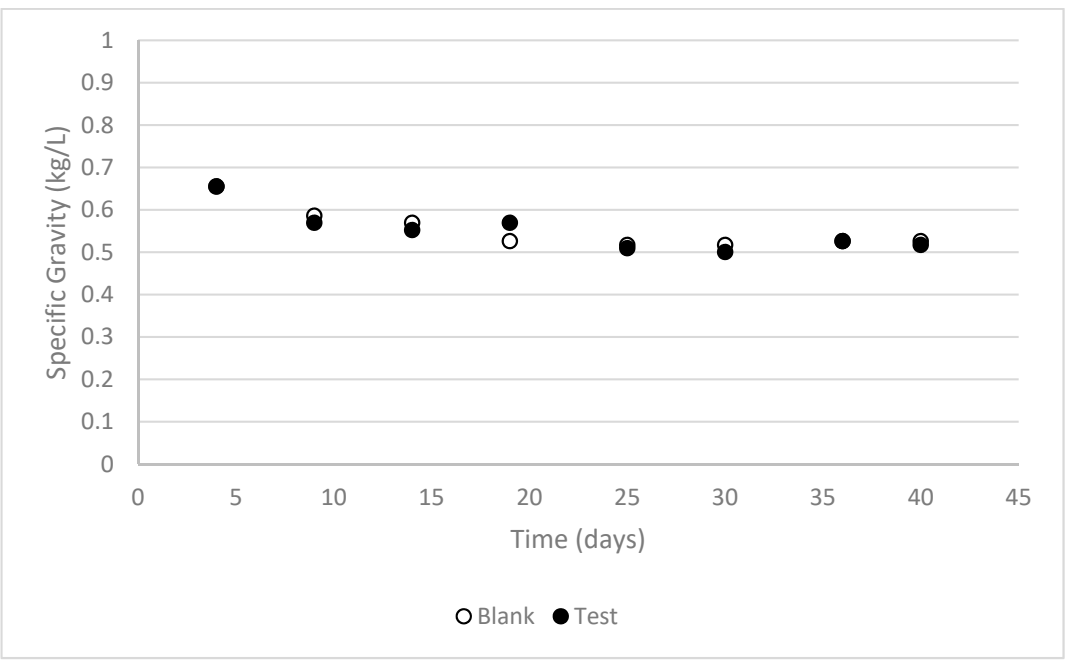

Figure 17. Change in bulk specific gravity with time. 
Table 5. Weights before and after the test.

\begin{tabular}{ccc}
\hline & Non-Treated Zone & Treated Zone \\
\hline Average weight of the compost (dry weight) & $59.95 \mathrm{~kg}(29.26 \mathrm{~kg})$ & $60.05 \mathrm{~kg}(31.67 \mathrm{~kg})$ \\
Average weight of the test specimen & \\
Before charge (water content) & $1.1 \mathrm{~kg}(6.3 \%)=1.031 \mathrm{~kg}$ as dry \\
After test (water content) & $0.067 \mathrm{~kg}(24.82 \%)=0.054 \mathrm{~kg}$ as dry \\
Residual rate of the test specimen & $5.23 \%$ (compared in dry weight) \\
\hline
\end{tabular}

\subsubsection{Quality of Inputs and Composted Products}

The elution test of the input materials was conducted based on the Waste Management and Public Cleaning Act [14] in Japan. As shown in Table 6, the results were all below the requirements for heavy metals, organophosphorus compounds, and other regulated compounds.

Table 6. Analysis results of items specified in the Waste Management and Public Cleaning Act (unit: $10^{-3} \mathrm{~kg} / \mathrm{m}^{3}$ ).

\begin{tabular}{cccccc}
\hline Analysis Item & Blank 1 & Blank 2 & Test 1 & Test 2 & Standard Value \\
\hline alkyl mercury compounds & $<0.0005$ & $<0.0005$ & $<0.0005$ & $<0.0005$ & not detected \\
mercury or its compounds & $<0.0005$ & $<0.0005$ & $<0.0005$ & $<0.0005$ & $\leq 0.0005$ \\
cadmium or its compounds & $<0.002$ & $<0.002$ & $<0.002$ & $<0.002$ & $\leq 0.3$ \\
lead or its compounds & $<0.01$ & $<0.01$ & $<0.01$ & $<0.01$ & $\leq 0.3$ \\
organophosphorus compounds & $<0.001$ & $<0.001$ & $<0.001$ & $<0.001$ & $\leq 1$ \\
chromium (VI) compounds & $<0.05$ & $<0.05$ & $<0.05$ & $<0.05$ & $\leq 1.5$ \\
arsenic or its compounds & 0.031 & 0.030 & 0.031 & 0.030 & $\leq 0.3$ \\
cyan compounds & $<0.1$ & $<0.1$ & $<0.1$ & $<0.1$ & $\leq 1$ \\
polychlorinated biphenyls & $<0.0005$ & $<0.0005$ & $<0.0005$ & $<0.0005$ & $\leq 0.003$ \\
trichloroethylene & $<0.001$ & $<0.001$ & $<0.001$ & $<0.001$ & $\leq 0.3$ \\
tetrachloroethylene & $<0.001$ & $<0.001$ & $<0.001$ & $<0.001$ & $\leq 0.1$ \\
dichloromethane & $<0.001$ & $<0.001$ & $<0.001$ & $<0.001$ & $\leq 0.2$ \\
carbon tetrachloride & $<0.001$ & $<0.001$ & $<0.001$ & $<0.001$ & $\leq 0.02$ \\
1,2-dichloroethane & $<0.001$ & $<0.001$ & $<0.001$ & $<0.001$ & $\leq 0.04$ \\
1,1-dichloroethylene & $<0.001$ & $<0.001$ & $<0.001$ & $<0.001$ & $\leq 0.2$ \\
cis-1,2-dichloroethylene & 0.004 & $<0.001$ & $<0.001$ & $<0.001$ & $\leq 0.4$ \\
1,1,1-trichloroethane & $<0.001$ & $<0.001$ & $<0.001$ & $<0.001$ & $\leq 3$ \\
1,1,2-trichloroethane & $<0.001$ & $<0.001$ & $<0.001$ & $<0.001$ & $\leq 0.06$ \\
1,3-dichlorobenzene & $<0.001$ & $<0.001$ & $<0.001$ & $<0.001$ & $\leq 0.02$ \\
benzene & $<0.001$ & $<0.001$ & $<0.001$ & $<0.001$ & $\leq 0.1$ \\
thiuram & $<0.006$ & $<0.006$ & $<0.006$ & $<0.006$ & $\leq 0.06$ \\
simazine & $<0.003$ & $<0.003$ & $<0.003$ & $<0.003$ & $\leq 0.03$ \\
thiobencarb & $<0.01$ & $<0.01$ & $<0.01$ & $<0.01$ & $\leq 0.2$
\end{tabular}

The composted products were analyzed by the test method based on the "Fertilizer Regulation Act" [15]. Table 7 shows the nutrient contents (e.g., moisture content, total nitrogen, total phosphoric acid). Table 8 shows the level of toxic items regulated by the Fertilizer Control Law (e.g., arsenic, cadmium, mercury). The results confirm that the compost is suitable for use as fertilizer.

\subsubsection{Confirmation of Effects on Plant Germination}

Finally, based on the practical test method [16] of plant growth, which measures the toxicity against plants and is related to the scope of ISO16929 [13], we confirmed the effect of the PLA sample-treated compost on plant germination. There were two test groups to grow komatsuna or Japanese mustard spinach. The control samples were grown in fertilizer from the pilot-scale compost without the PLA sample (B-1 and B-2), while the tests were grown in fertilizer from the pilot-scale compost with the PLA sample (T-1 and T-2). The komatsuna seeds were buried in each type of fertilizer. After three weeks, good growth was observed in both groups. Additionally, neither group showed abnormal growth (Table 9). Hence, the compost-treated product with the PLA sample did not induce harmful effect on plants, demonstrating its suitability as a good compost product. 
Table 7. Analysis results of nutrient items specified in the Fertilizer Control Law.

\begin{tabular}{cccccc}
\hline Analysis Item & Unit & Blank 1 & Blank 2 & Test 1 & Test 2 \\
\hline Water content & $\%$ & 44.5 & 44.2 & 43.8 & 44.0 \\
Total nitrogen amount & $\%$ & 1.54 & 1.57 & 1.36 & 1.44 \\
Total phosphoric amount & $\%$ & 0.96 & 0.99 & 0.96 & 0.96 \\
Total potassium amount & $\%$ & 1.58 & 1.64 & 1.67 & 1.66 \\
Total copper amount & $\mathrm{mg} / \mathrm{kg}$ & 23.1 & 22.4 & 23.9 & 23.9 \\
Total zinc amount & $\mathrm{mg} / \mathrm{kg}$ & 77.3 & 80.0 & 78.8 & 75.0 \\
Total lime amount & $\%$ & 0.88 & 0.86 & 0.91 & 0.88 \\
Organic carbon & $\%$ & 11.4 & 11.4 & 10.8 & 11.2 \\
Carbon/nitrogen ratio & & 7.4 & 7.3 & 7.9 & 7.8 \\
\hline
\end{tabular}

Table 8. Analysis results of toxic items specified in the Fertilizer Control Law (Unit: \%).

\begin{tabular}{cccccc}
\hline Analysis Item & Blank 1 & Blank 2 & Test 1 & Test 2 & Standard Value \\
\hline Arsenic & 0.0010 & 0.0007 & 0.0009 & 0.0009 & $<0.005$ \\
Cadmium & $<0.000005$ & $<0.000005$ & $<0.000005$ & $<0.000005$ & $<0.0005$ \\
Mercury & 0.00003 & $<0.000002$ & 0.00003 & $<0.000002$ & $<0.0002$ \\
Nickel & 0.003 & 0.003 & 0.008 & 0.007 & $<0.03$ \\
Chromium & $<0.005$ & $<0.005$ & $<0.005$ & $<0.005$ & $<0.05$ \\
Lead & $<0.001$ & $<0.001$ & $<0.001$ & $<0.001$ & $<0.01$ \\
\hline
\end{tabular}

Table 9. Test results of plant growth in fertilizer from pilot-scale compost.

\begin{tabular}{cccccccc}
\hline Zone & \multicolumn{3}{c}{ Rate of Germination } & \multicolumn{2}{c}{ Results of Growth } & Abnormality \\
\hline & $\begin{array}{c}\text { 1 Week } \\
\mathbf{( \% )}\end{array}$ & $\begin{array}{c}\text { 2 Weeks } \\
\mathbf{( \% )}\end{array}$ & $\begin{array}{c}\text { 3 Weeks } \\
\mathbf{( \% )}\end{array}$ & $\begin{array}{c}\text { Leaf length } \\
\text { 2 Weeks }(\mathbf{c m})\end{array}$ & $\begin{array}{c}\text { Leaf Length } \\
\text { 3 Weeks (cm) }\end{array}$ & $\begin{array}{c}\text { Weight } \\
\text { (g/pot) }\end{array}$ & \\
\hline B-1 & 100.0 & 100.0 & 100.0 & 5.0 & 7.7 & 16.5 & None \\
B-2 & 98.3 & 98.3 & 98.3 & 5.2 & 8.2 & 18.7 & None \\
T-1 & 98.3 & 98.3 & 98.3 & 4.8 & 7.5 & 15.3 & None \\
T-2 & 98.3 & 98.3 & 98.3 & 5.7 & 7.6 & 16.2 & None \\
\hline
\end{tabular}

\subsubsection{Insight from the History of PLA Degradation in Compost}

Prior to our experiments, we surveyed the literature from 1992 to 2019 to analyze previous research on pilot-scale biodegradability and safety of the resulting compost. Many papers published from the 1990s to the early 2000s were related to the promotion of PLA polymers' biodegradability [17-25]. Some studies also worked to improve the mechanical properties by producing copolymers [18] or blending with other biodegradable polymers [20,24] and additives [22]. Other studies reported direct and simple biodegradability testing of PLA [26,27], and socially implementable biodegradability experiments using compost [28-30]. However, full-scale studies on the biodegradability and disintegration results utilizing existing real composting facilities for commercially available PLA products only began to appear around 2005.

In 2006 and 2007, papers were published demonstrating the degradability of a variety of commercial PLA products in compost such as cheese packaging [31], carpet and fiber products [32], bottles, trays and deli-containers [33], and knives and packaging [34]. In one study [33], three commercially available forms of PLA packaging and containers were exposed to real composting conditions at Michigan State University under ambient exposure conditions. Degradation in a real composting facility was monitored by visual inspections, gel permeation chromatography, differential scanning calorimetry, and thermal gravimetric analysis. The authors noted the need to address the compostability of these packages under real composting conditions for social implementation since the standard methodology of evaluating biodegradability in simulated composting conditions has limitations. They also showed that the compostability of the complete package in real composting conditions may take longer than a simple piece of polymer.

Professor Narayan, who is a leader in research on biodegradable polymers, and colleagues have published many papers regarding biodegradability. Among these, two 
papers compared ASTM/ISO tests with realistic composting conditions in 2007 [35] and 2009 [36]. Based on their disintegration tests on real compost (fresh compost) using PLA bottles, they pointed out that standard test methods such as ISO 14855 only answer whether a plastic is biodegradable [10]. Standard methods do not answer the question of whether it is fully biodegradable in an actual compost facility. This follows on from ISO 17088, which was announced in 2008 and revised in 2019 [37].

From industrial and business perspectives, major consumer goods companies have documented [38] that it is pointless to use PLA and other biodegradable plastic products unless they are properly processed in a composting plant. Without proper composting, they will not contribute to waste reduction.

In 2017, a paper was published that questioned the decomposability of compost in actual facilities, even if decomposition is demonstrated on the laboratory scale [39]. They argued that compost facilities vary in operational methods, and the actual degradability depends on the form. As the above studies show, it is important to confirm biodegradability in actual composting facilities as social implementation of bioplastics with biodegradable properties such as PLA progresses. All the messages delivered by the above papers are similar to the one that this paper tries to convey.

There are few examples demonstrating the safety of PLA by assessing plant growth in the literature. A paper in 2019 questioned the safety of micro and nanoparticles, which is a concern during decomposition of PLA products, including their additives [40]. In many practical available resins, various additives are used in the manufacturing process. Hence, it is necessary to investigate whether such additives decompose in real compost. Additionally, we need to evaluate the safety of the decomposed material and the resulting compost. However, it appears that few studies demonstrate the method and results of such a comprehensive and holistic approach on the pilot scale.

\subsubsection{Influencing Elements Affecting the Biodegradability Time in Compost}

To date, the biodegradability of PLA in compost has been demonstrated on the laboratory scale according to ISO 14855 [10]. Consistent with our previous paper [3], this study shows that more than $80 \%$ of PLA biodegrades in 80 days using mature compost (Figures 2 and 6). According to the paper by M. Kunioka et al. on the Biodegradability Evaluation of Polymers by ISO 14855-2 [12], they found that $80 \%$ or more of the powder was biodegraded after 50 days [41]. In contrast, when a sample is shaped into PLA cups, it takes 100 days or more to reach a minimum of $80 \%$ decomposition. Hence, the sample shape affects decomposition time.

ISO 14855 tracks the biodegradability by the amount of $\mathrm{CO}_{2}$ generated [10]. On the other hand, this study used ISO 16929, which assesses the contents of the fermenter after testing and sieving [10]. The decomposition rate was subsequently calculated by comparing the dry weight of the remaining PLA sample and the original PLA sample. Such a comparison is challenging. Here, if degradation is considered to be complete at the time when the temperature, $\mathrm{CO}_{2}$ concentration, and weight in the container stopped changing, it means that $94.8 \%$ of the PLA sample was degraded in 50-60 days. Comparing the above results in laboratory-scale and pilot-scale studies, the degradability on the laboratory scale and the pilot scale was at least equivalent when considering the sample shape, and suggest a slightly faster degradation time on the pilot scale.

\subsubsection{Holistic Approach and Social Implementation}

This study investigates both the biodegradability and disintegration property of the product in the compost. The PLA samples did not adversely affect the composting process. The quality and safety of the obtained compost were maintained. Such results are difficult to obtain in a laboratory-scale test. However, the pilot-scale test provided results suitable as a proof of concept for social implementation. That is, a pilot-scale test was used as a holistic approach to demonstrate the feasibility compost facilities to process PLA products. 
PLA products have been used in two major global events for social implementation: the Kassel project [42-45] and the Aichi EXPO [46]. The Kassel project ran from 2001 to 2002 in the city of Kassel, Germany. PLA film-laminated paper plates were used in a supermarket. After use, they were collected, sorted, and safely composted. During the Aichi EXPO in Japan, single-use and compostable tableware made from PLA was used in the food court and composted after use. In both cases, vegetables were grown in the resulting compost. Beside the global events described above, garbage bags made of PLA were introduced in Kosaka Town, Akita Prefecture, and Furano City [47,48]. Organic waste was also collected from homes in Hokkaido and treated in composting facilities. The resulting compost was used as fertilizer in domestic farms. Additionally, some companies have focused on the closed system, which is beyond the involvement adopted in business models based on related holistic approaches and is drawing attention from the viewpoint of a circular economy. In Colorado, USA, a hamburger chain minimized the use of packaging and containers, and introduced biobased and biodegradable packaging and cups made of paper and PLA [49]. The environmental contribution was not made through use of the material itself but rather the recovery and composting treatment implemented after use.

\section{Conclusions}

PLA film-laminated paper, which was used as the test sample representing commercial products, does not affect the fermentation status of the composting process. However, it does satisfy the various conditions shown in the "Plastic disintegration under composting conditions" described in ISO 16929. In addition, the elution test of the input materials meets the requirements specified in "Waste Management and Public Cleaning Act", and an analysis of the obtained compost based on the "Fertilizer Regulation Act" indicates that it does not suffer from quality problems. Adverse plant growth did not occur even if the compost contained residual residues of the PLA sample. Consequently, composting treatment of the organic waste together with biodegradable plastics such as PLA will contribute to a circular economy by adding value to waste. This comprehensive and holistic pilot-scale demonstration test shows that the composting process of PLA products after use is effective in social implementation and meaningful for creating a social framework.

Author Contributions: Conceptualization, methodology, formal analysis, and supervision by T.Y. and N.K.; writing-original draft preparation by K.K. and N.K.; writing—review and editing by N.K. All authors have read and agreed to the published version of the manuscript.

Funding: This research received no external funding.

Institutional Review Board Statement: Not applicable.

Informed Consent Statement: Not applicable.

Data Availability Statement: Not applicable.

Acknowledgments: The authors thank Shin Fukuda, Shingo Shibata, Kiyoshi Ito, Ken Migita, and Toshie Sato for their support and insight. The authors also thank Tadahisa Iwata, The University of Tokyo and Hiroyasu Yamaguchi, Osaka University for their advice and instruction.

Conflicts of Interest: The authors declare no conflict of interest.

\section{References}

1. Steinbüchel, A. Biopolymers, 1st ed.; Wiley-VCH: Weinheim, Germany, 2004; Volume 4.

2. Iwata, T. Biodegradable and bio-based polymers: Future prospects of eco-friendly plastics. Angew. Chem. Int. Ed. 2015, 54, 3210-3215. [CrossRef]

3. Kawashima, N.; Ogawa, S.; Obuchi, S.; Matsuo, M.; Yagi, T. Polylactic acid “LACEA”. In Biopolymers; Doi, Y., Steinbüchel, A., Eds.; Wiley-VCH: Weinheim, Germany, 2004; Volume 4, pp. 251-274.

4. Kawashima, N.; Yagi, T.; Kojima, K. How do bioplastics and fossil-based plastics play in a circular economy? Macromol. Mater. Eng. 2019, 304, 1900383. [CrossRef] 
5. The Ellen MacArthur Foundation. Towards the Circular Economy, Economic and business rationale for an Accelerated Transition. Available online: https:/ / www.ellenmacarthurfoundation.org/assets/downloads/publications/Ellen-MacArthur-FoundationTowards-the-Circular-Economy-vol.1.pdf (accessed on 14 December 2020).

6. Kawashima, N. How do fossil-based plastics and bioplastics play in a circular economy? Polymer Preprints. In Proceedings of the 69th SPSJ Annual Meeting, Fukuoka, Japan, 29 May 2020; Volume 69.

7. Castro-Aguirre, E.; Iniguez-Franco, F.; Samsudin, H.; Fang, X.; Auras, R. Poly(lactic acid)—Mass production, processing, industrial applications and end of life. Adv. Drug Deliv. Rev. 2016, 107, 333-366. [CrossRef]

8. Gruber, P.R.; O’Brien, M. In Biopolymers. In Biopolymers Online; Steinbüchel, A., Ed.; Wiley-VCH: Weinheim, Germany, 2005; pp. 235-239.

9. Ajioka, M.; Enomoto, K.; Suzuki, K.; Yamaguchi, A. The basic properties of poly(lactic acid) produced by the direct condensation polymerization of lactic acid. J. Environ. Polym. Degr. 1995, 3, 225-234. [CrossRef]

10. International Organization for Standardization (ISO) Determination of the Ultimate Aerobic Biodegradability and Disintegration of Plastic Materials under Controlled Composting Conditions-Method by Analysis of Evolved Carbon Dioxide (Standard No. 14855). 1999. Available online: https://www.iso.org/standard/25769.html (accessed on 14 December 2020).

11. International Organization for Standardization (ISO). Determination of the Ultimate Aerobic Biodegradability of Plastic Materials under Controlled Composting Conditions-Method by Analysis of Evolved Carbon Dioxide-Part 1: General Method (Standard No. 14855-1). 2005. Available online: https://www.iso.org/standard/42155.html (accessed on 14 December 2020).

12. International Organization for Standardization (ISO). Determination of the Ultimate Aerobic Biodegradability of Plastic Materials under Controlled Composting Conditions-Method by Analysis of Evolved Carbon Dioxide_-Part 2: Gravimetric Measurement of Carbon Dioxide Evolved in a Laboratory-Scale Test (Standard No. 14855-2). 2018. Available online: https://www.iso.org/ standard/72046.html (accessed on 14 December 2020).

13. International Organization for Standardization (ISO). Plastics-Determination of the Degree of Disintegration of Plastic Materials under Defined Composting Conditions in a Pilot-Scale Test (Standard No. 16929). 2013. Available online: https://www.iso.org/ standard/62948.html (accessed on 14 December 2020).

14. The Waste Management and Public Cleaning Law, Act No. 137 of 1970: Promulgated in 25 December 1970 in Japan. Available online: https: / / elaws.e-gov.go.jp/search/elawsSearch/elaws_search/lsg0500/detail?lawId=348M50000002005 (accessed on 14 December 2020).

15. Fertilizer Regulation Act: Matters Such as Establishing Official Standards for Ordinary Fertilizers Based on the Fertilizer Regulation Act in Japan. Available online: http:/ / www.famic.go.jp/ffis/fert/obj/shikenho_2020.pdf\#page=1 (accessed on 14 December 2020).

16. 1Cultivation Test Methods to Evaluate Harm to Plants Regulated by the Ministry of Agriculture, Forestry and Fisheries in Japan. Available online: http:/ / www.famic.go.jp/ffis/fert/sub2_7.html (accessed on 14 December 2020).

17. Nakayama, Y.; Yasuda, H.; Yamamoto, K.; Tsutsumi, C.; Jerome, R.; LeComte, P. Comparison of Sm complexes with Sn compounds for syntheses of copolymers composed of lactide and cyclic carbonates and their biodegradabilities. React. Funct. Polym. 2005, 63, 95-105. [CrossRef]

18. Yasuda, H.; Yamamoto, K.; Nakayama, Y.; Tsutsumi, C.; Lectomte, P.; Jerome, R.; McCarthy, S.; Kaplan, D. Comparison of Sm complexes with Sn compounds for syntheses of copolymers composed of lactide and $\varepsilon$-caprolactone and their biodegradabilities. React. Funct. Polym. 2004, 61, 277-292. [CrossRef]

19. Copinet, A.; Bertrand, C.; Longieras, A.; Coma, V.; Couturier, Y. Photodegradation and biodegradation study of a starch and poly(lactic acid) coextruded material. J. Polym. Environ. 2003, 11, 169-179. [CrossRef]

20. Shinoda, H.; Asou, Y.; Kashima, T.; Kato, T.; Tseng, Y.; Yagi, T. Amphiphilic biodegradable copolymer, poly(aspartic acid-colactide): Acceleration of degradation rate and improvement of thermal stability for poly(lactic acid), poly(butylene succinate). Polym. Degrad. Stab. 2003, 80, 241-250. [CrossRef]

21. Ray, S.S.; Yamada, K.; Okamoto, M.; Ueda, K. Control of biodegradability of polylactide via nanocomposite technology. Macromol. Mater. Eng. 2003, 288, 203-208. [CrossRef]

22. Ray, S.; Yamada, K.; Okamoto, M.; Ueda, K. New polylactide-layered silicate nanocomposites. 2. Concurrent improvements of material properties, biodegradability and melt rheology. Polymer 2003, 44, 857-866.

23. Gattin, R.; Copinet, A.; Bertrand, C.; Couturier, Y. Biodegradation study of a starch and poly(lactic acid) co-extruded material in liquid, composting and inert mineral media. Int. Biodeterior. Biodegrad. 2002, 50, 25-31. [CrossRef]

24. McCarthy, S.P.; Ranganthan, A.; Ma, W. Advances in properties and biodegradability of co-continuous, immicisible, biodegradable, polymer blends. Macromol. Symp. 1999, 144, 63-72. [CrossRef]

25. Ma, W.; McCarthy, S.P. Biodegradable polymer blends of polylactic acid (PLA) and polybutylene succinate. In Proceedings of the Society of Plastics Engineers Annual Technical Conference, Atlanta, Georgia, 26-30 April 1998; Volume 56, pp. $2542-2545$.

26. Itaevaara, M.; Karjomaa, S.; Selin, J.-F. Biodegradation of polylactide in aerobic and anaerobic thermophilic conditions. Chemosphere 2002, 46, 879-885. [CrossRef]

27. Yamanaka, K.Y. Lactron-A biodegradable fiber, its development and applications. Chem. Fibers Int. 1999, 49, 501-503.

28. Yang, H.-S.; Yoon, J.-S.; Kim, M.-N. Dependence of biodegradability of plastics in compost on the shape of specimens. Polym. Degrad. Stab. 2005, 87, 131-135. [CrossRef] 
29. Ho, K.-L.G.; Pometto, A.L., III; Gadearivas, A.; Briceno, J.A.; Rojas, A. Degradation of polylactic acid (PLA) plastic in Costa Rican soil and Iowa State University compost rows. J. Environ. Polym. Degrad. 1999, 7, 173-177. [CrossRef]

30. Schlicht, R. Kompostierbare Joghurt-Becher. Kunststoffe Plast Eur. 1998, 88, 888-890.

31. Plackett, D.V.; Holm, V.K.; Johansen, P.; Ndoni, S.; Nielsen, P.V.; Sipilainen-Malm, T.; Södergård, A.; Verstichel, S. Characterization of L-polylactide and L-polylactide-polycaprolactone co-polymer films for use in cheese-packaging applications. Packag. Technol. Sci. 2006, 19, 1-24. [CrossRef]

32. Hensler, C. Biobased fabric composting trial. Biocycle 2006, 47, 50-51.

33. Kale, G.; Auras, R.; Singh, S.P. Degradation of commercial biodegradable packages under real composting and ambient exposure conditions. J. Polym. Environ. 2006, 14, 317-334. [CrossRef]

34. Greene, J. Biodegradation of compostable plastics in green yard-waste compost environment. J. Polym. Environ. 2007, 15, 269-273. [CrossRef]

35. Kale, G.; Aurus, R.; Singh, S.P.; Narayan, R. Biodegradability of polylactide bottles in real and simulated composting conditions. Polym. Test. 2007, 26, 1049-1061. [CrossRef]

36. Kijchavengkul, T.; Kale, G.; Auras, R. Degradation of biodegradable polymers in real and simulated composting conditions. In Polymer Degradation and Performance of the ACS Symposium Series; Celina, M.C., Wiggings, J.S., Billingham, N.C., Eds.; Division of Polymer Chemistry in American Chemical Society: Washington, DC, USA, 2009; Volume 1004, pp. 31-40.

37. International Organization for Standardization (ISO). Specifications for Compostable Plastics (Standard No. 17088). 2008. Available online: https:/ / www.iso.org/standard/43373.html (accessed on 14 December 2020).

38. Pandis, C. Sustainability in plastics-Embracing new approaches. Glob. Cosmet. Ind. 2011, 179, 62-63.

39. Zhanga, H.; McGill, E.; Gomez, C.O.; Carson, S.; Neufeld, K.; Hawthorne, I.; Smukler, S.M. Disintegration of compostable foodware and packaging and its effect on microbial activity and community composition in municipal composting. Int. Biodeterior. Biodegrad. 2017, 125, 157-165. [CrossRef]

40. Sintim, H.Y.; Bary, A.I.; Hayes, D.G.; English, M.E.; Schaeffer, S.M.; Miles, C.A.; Zelenyuk, A.; Suski, K.; Flury, M. Release of micro- and nanoparticles from biodegradable plastic during in situ composting. Sci. Total Environ. 2019, 675, 686-693. [CrossRef] [PubMed]

41. Funabashi, M.; Ninomiya, F.; Kunioka, M. Biodegradability evaluation of polymers by ISO 14855-2. Int. J. Mol. Sci. 2009, 10, 3635-3654. [CrossRef]

42. Bidlingmaier, W.; Jakobi, A.; Kaeb, H.; Klauss, M.; Lichtl, M. Kassel Project; Narcon Innovation Consulting; Lichtl Sustainability Communications, and IBAW: Berlin, Germany, 2003.

43. Reske, J. Biodegradable Polymers and Plastics; Chiellini, E., Solaro, R., Eds.; Springer: Boston, MA, USA, 2003 ; pp. 73-80.

44. Klauss, M. Biodegradable polymer packaging_Practical experiences of the model project Kassel. Waste Manag. $2004,24,43-51$. [CrossRef]

45. Warmington, A. Biodegradables take off. Eur. Plast. News 2002, 29, 21.

46. Ohshima, K. Technical Seeds and Future Direction of Biopolymers. 2009. Available online: https://www.rish.kyoto-u.ac.jp/ labm/wp-content/uploads/2012/07/nedo20090430-05.pdf (accessed on 14 December 2020).

47. Furano District Environmental Hygiene Center. Available online: https://www.furano.ne.jp/eiseikumiai/hp.pdf/factoryintroduction. pdf (accessed on 14 December 2020).

48. How to Sort and Put Garbage Out in Furano City. Available online: https://www.furano.ne.jp/eiseikumiai/hp.pdf/ awayofthegarbage.pdf (accessed on 14 December 2020).

49. Larkburger and Compostability. Available online: https://www.youtube.com/watch?v=m26JP2RnC3o (accessed on 14 December 2020). 